\title{
AS NEGAÇÕES DO NARRADOR EM A HORA DA ESTRELA E EM SUA TRADUÇÃO PARA A LÍNGUA INGLESA: (POSSÍVEIS) INTERFACES ENTRE A LINGUÍSTICA SISTÊMICO-FUNCIONAL E A PSICANÁLISE
}

\author{
THE NARRATOR'S DENIALS IN A HORA DA ESTRELA \\ AND IN ITS TRANSLATION INTO ENGLISH: (POSSIBLE) \\ INTERFACES BETWEEN SYSTEMIC-FUNCTIONAL \\ LINGUISTICS AND PSYCHOANALYSIS
}

\author{
Lissa Russano Trench ${ }^{1}$ \\ [https://orcid.org/0000-0002-0286-2224] \\ Adail Sebastião Rodrigues-Júnior ${ }^{2}$ \\ [https://orcid.org/0000-0003-1932-2862] \\ DOI: 10.30612/raido.v15i37.12837
}

RESUMO: Esta pesquisa objetiva analisar ocorrências de negaçáo na voz do narrador de A hora da estrela, de Clarice Lispector, em comparaçáo com sua segunda traduçăo para a língua inglesa, de modo a explorar o papel discursivo da negaçăo para a construçâo de sentidos subjetivos do narrador em relaçăo à Macabéa, personagem principal. Esta análise pauta-se em estudos sobre negativas orientados pela Linguística SistêmicoFuncional (MARTIN \& ROSE, 2007; HALLIDAY, 2014; PAGANO, 1994), em diálogo com o conceito de negaçăo freudiano (FREUD, 2014). De forma complementar, nos respaldamos também em estudos que tratam da interrelaçăo entre linguagem e psicanálise (DOMINE, 2015; FROTA, 2013, 2015). A análise dos dados localiza-se nas ocorrências em que a marca da negaçăo sinaliza textualmente o inconsciente recalcado do narrador projetado em Macabéa, de quem ele tenta se desvincular. Em seguida buscamos estabelecer um diálogo entre os discursos de negaçăo expressos a partir de uma perspectiva textual e os que se fundamentam na psicanálise. As análises indicam que as negaçôes do narrador revelam seu incômodo próprio projetado em Macabéa. Ao negar-se na personagem, o narrador acaba por reconhecer-se nela, o que foi possível de ser percebido graças à presença da negaçáo em seu texto.

Palavras-chave: A Hora da Estrela; Traduçâo Literária; Linguística Sistêmico-Funcional; Psicanálise; Negaçâo.

1 Graduanda em Letras-Bacharelado em Traduçăo pela Universidade Federal de Ouro Preto. Desenvolve pesquisa no campo da traduçăo literária em diálogo com a Linguística e a Psicanálise. E-mail: lissa russano@homail.com

2 Doutor em Linguística Aplicada pela UFMG, com estágio pós-doutoral em Estudos da Linguagem pelo LAEL/PUC-SP. Professor de Traduçăo do Departamento de Letras da Universidade Federal de Ouro Preto. Desenvolve pesquisa no campo da traduçâo literária em diálogo com a Linguística e a Psicanálise.

E-mail: adail.junior@ufop.edu.br 
ABSTRACT: This studyaims to analyze the occurrences of denial in the voice of the narrator of A hora da estrela, by Clarice Lispector, in comparison with its second translation into English, in order to explore the discursive role of denial for the construction of subjective meanings of the narrator in relation to Macabéa, main character. This analysis is based on studies on negatives oriented by Systemic-Functional Linguistics (MARTIN \& ROSE, 2007; HALLIDAY, 2014; PAGANO, 1994), in dialogue with Freud's concept of denial (FREUD, 2014). In a complementary way, we also rely on studies that deal with the interrelation between language and psychoanalysis (DOMINE, 2015; FROTA, 2013, 2015). The analysis of the data lies in those occurrences in which the mark of denial textually signals the repressed unconscious of the narrator projected in Macabéa, from whom he tries to dissociate himself. We then seek to establish a dialogue between the discourses of denial expressed from a textual perspective and those based on psychoanalysis. The analyses indicate that the narrator's denials reveal his own discomfort projected in Macabéa. By denying himself in the character, the narrator ends up recognizing himself in her, which was possible to be perceived due to the presence of denial in his text.

Keywords: The Hour of the Star; Literary Translation; Systemic-Functional Linguistics; Psychoanalysis; Denial.

\section{INTRODUÇÃO $0^{3}$}

A Hora da Estrela ${ }^{4}$ última obra de Clarice Lispector, publicada em 1977 pouco antes do falecimento da autora, conta a história de uma moça, tăo pobre que só comia cachorro-quente. Porém, segundo Clarice em uma entrevista para a TV Cultura no início desse mesmo ano, "a história năo é isso, é sobre uma inocência pisada de uma miséria anônima." E acrescenta: "Esta história acontece em estado de emergência e calamidade pública. Trata-se de um livro inacabado porque lhe falta a resposta." (LISPECTOR, 2017, p. 46). Na dedicatória do livro, a autora deixa claro que se converterá em um ser fictício, um narrador masculino, como se fosse outra faceta de sua personalidade. Assim, Rodrigo S. M. se apresenta como escritor amador, julgando ter sido "mesmo um pouco contente" até o momento em que uma moça nordestina surgiu em sua vida.

Inquieto e angustiado, o narrador divaga pelo texto por meio de uma escrita metalinguística, por meio da qual tenciona refletir sobre qual seria a melhor forma de nos contar a história da moça. Nessa parte do texto, observa-se a ocorrência do tipo de metalinguagem que faz reflexóes acerca do trabalho do escritor, pontuando toda a narrativa com questionamentos referentes à atividade intelectual e ao fazer literário. A partir do momento em que o narrador se encoraja, o monólogo metalinguístico de Rodrigo S. M. cede espaço ao início de seus relatos sobre a vida da nordestina:

3 Os autores agradecem a leitura atenta e as sugestôes dos pareceristas do comitê científico da Revista Raído.

4 Outros títulos aspirados pela escritora: A culpa é minha, Ela que se arranje, O direito ao grito, Quanto ao futuro, Lamento de um blue, Ela năo sabe gritar, Uma sensaçâoo de perda, Assovio no vento escuro, Eu nâo posso fazer nada, Registro dos fatos antecedentes, História lacrimogenica de cordel, Saída discreta pela porta dos fundos 
seus sonhos, manias e conflitos internos. No decorrer da obra, sua interaçấo com a personagem oscila entre identificaçâo e afastamento, uma vez que apesar de suas aparentes diferenças, ambos compartilham a busca pela própria identidade.

Interessante percebermos a maneira como, ao contar a história de Macabéa, o narrador revela, ora direta, ora indiretamente, seus próprios desejos, fraquezas e falhas. Nesse contexto, a ocorrência de elementos de negaçăo se expressa de forma contundente ao longo do discurso narrativo. Tais marcas de negaçăo nos permitem refletir sobre o perfil discursivo do narrador Rodrigo S. M., que corrobora a hipótese da pesquisa, a qual aponta para o fato de que por meio das marcas discursivas de negaçâo, o narrador projeta suas frustraçóes reprimidas na personagem principal. É com foco nessas marcas que este estudo analisa as ocorrências das negaçóes presentes na voz do narrador de A hora da estrela, em comparaçáo com a traduçấo dessa obra para a língua inglesa, feita por Benjamin Moser. Tal análise será feita a partir de uma perspectiva semântico-discursiva sobre a negaçăo orientada pela Linguística Sistêmico-Funcional (HALLIDAY \& MATTHIESSEN, 2014; MARTIN \& ROSE, 2007; PAGANO, 1994), em diálogo com a Psicanálise freudiana (FREUD, 2014 [1925]; ZIMMERMAN, 2008) e com base em estudos pautados na inter-relaçâo entre linguagem e psicanálise (FROTA, 2013, 2015; MARÍN-DOMINE, 2015).

\section{NEGAÇÕES NO ÂMBITO DA LINGUÍSTICA SISTÊMICO-FUNCIONAL E DA PSICANÁLISE}

As negaçōes săo marcas discursivas próprias do campo semântico da polaridade. Halliday (2014) as entende como realizaçấo linguística presente no extremo oposto do polo da modalidade; ou seja, enquanto o "náo" apresenta polaridade alta, outras realizaçóes como "provavelmente năo", "talvez năo" etc. apresentam modalizaçôes que diminuem a força discursiva da negaçăo até chegar ao campo semântico da afirmaçăo. Esse eixo de instanciaçăo (cline of instantiation) discutido por Halliday (2014) apresenta uma finitude de escolhas linguísticas que constituem a maneira como falantes e escritores optam por posicionar-se perante seus ouvintes e leitores nesse campo semântico específico. A essa "maneira" Halliday (2014) deu o nome de condiçấo de entrada (entry condition), isto é, um conjunto de alternativas linguísticas possíveis e típicas do sistema de modalidade da língua em uso, representada na FIG.1 a seguir:

FIG. 1: Eixo de polaridade - Modalidade

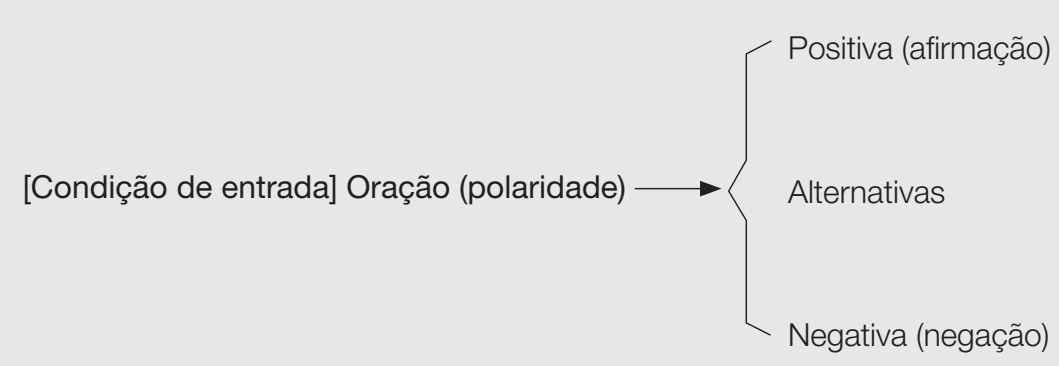

Fonte: Adaptado de Halliday (2014, p. 22). 
Vê-se que as negaçóes propriamente ditas ocupam um extremo do eixo de instanciaçăo, ao passo que as afirmativas ocupam o outro extremo. Nesse intermeio, há uma finitude de escolhas modalizadas de negaçôes - alternativas - que as aproximam ou do extremo da afirmaçấo, ou do da negaçâo. Há, portanto, várias escolhas linguísticas para as negaçóes que, năo necessariamente, ocupam o campo semântico restrito da polaridade negativa realizada linguisticamente pelo advérbio "năo". Alternativas, como, por exemplo, "certamente năo", "provavelmente năo", "talvez năo" etc. compóem esse quadro de escolhas, que mostra que há inúmeras formas de se posicionar por meio do discurso usando as negaçóes.

Pagano (1994), por exemplo, afirma que por meio da negaçăo o sujeito expressa sua visăo em relaçăo a algo. Martin e Rose (2007), por sua vez, ampliaram essa discussăo ao concluírem que as negaçōes posicionam sua voz em oposiçăo ao outro polo do eixo de instanciaçâo, nesse caso, as afirmaçôes. Para esses autores, as negaçôes têm sentido se situadas nessa oposiçăo, por demandarem, no âmbito argumentativo, um referente positivo, ao passo que as afirmaçôes por si bastam, por năo necessitarem invocar uma voz negativa que as respalde. Em outras palavras, enquanto a afirmaçâo traz um conteúdo discursivo unificado, pronto, sem a necessidade de referentes opostos, as negaçóes somente fazem sentido se expressas em relaçâo a um referente oposto, no caso, uma afirmaçăo sendo contestada.

A partir dessa perspectiva semântico-discursiva, visamos analisar, em diálogo com o conceito de (de)negaçăo de Sigmund Freud (2014[1925]), a presença de ocorrências de negaçâo na voz do narrador de A Hora da Estrela, de Clarice Lispector, em comparaçăo com a traduçáo dessa obra para a língua inglesa, feita por Benjamin Moser ${ }^{5}$, de modo a explorar seu papel discursivo para a construçăo de sentidos subjetivos do narrador projetados na personagem principal, Macabéa.

O método analítico de Freud considera a negaçăo da seguinte forma:

É um mecanismo defensivo do ego que consiste no fato de o sujeito recusar a percepçáo de uma evidência que se impóe no mundo exterior, da mesma forma que, na situaçấo psicanalítica, nega as evidências do que está reprimido. Por exemplo, quando uma pessoa recusa, dizendo năo (nunca desejei tal coisa) é muito possível que esteja querendo confirmar (sim, meu inconsciente deseja tal coisa). (ZIMMERMAN, 2008, p. 99).

Em outras palavras, a negaçăo seria, para Freud, uma espécie de "mecanismo de defesa" que se concretiza no discurso a partir do recalque, que é, pois, a lembrança que náo quer ser rememorada. Dessa forma, a cena bloqueada, imersa no inconsciente, compóe o conjunto de lembranças com o qual o sujeito năo quer ter contato; para ele, é mais segura a ilusăo do esquecimento, visto que o objeto esquecido é indesejado (Cf. RODRIGUES-JÚNIOR, s/d). Essa dinâmica é explicada por Freud em seu texto Die Verneinung (A Negaçâo, 2014 [1925]), em que discute a forma como o analista pode vir a tomar conhecimento do reprimido ao desconsiderar as negaçôes dos analisandos.

5 Para os objetivos desta pesquisa, utilizamos a ediçâo: LISPECTOR, C. A Hora da Estrela. 1ed. Rio de Janeiro: Rocco, 2017. Sobre a traduçâo, utilizamos a ediçâo: LISPECTOR, C., The Hour of The Star. Trad. Benjamin Moser. London, England: Penguin G, 2014. 
Nesse contexto, Freud ainda afirma: "Năo há prova mais forte de que conseguimos descobrir o inconsciente do que quando o analisando reage com a frase: 'Isso eu nâo tinha pensado', ou 'Nisso eu nâo tinha pensado (nunca)'". Segundo ele:

O modo como os nossos pacientes apresentam as ideias que lhes ocorrem durante o trabalho analítico nos dá a oportunidade de fazer algumas observaçóes interessantes. "Agora o senhor vai pensar que quero dizer algo ofensivo, mas realmente năo tenho essa intençăo." Entendemos que isso é uma rejeiçăo, por projeçăo, de uma ideia emergente naquele momento. Ou entăo: "O senhor pergunta quem pode ser essa pessoa no sonho. Minha mâe năo é". E nós retificamos: logo, é a măe. Na interpretaçăo tomamos a liberdade de desconsiderar a negaçăo, extraindo o puro conteúdo da ideia. É como se o paciente tivesse dito: “Na verdade foi minha măe que me ocorreu com relaçăo a essa pessoa, mas náo tenho a menor vontade de admitir essa ideia". (FREUD, 2014, p. 10)

Freud esclarece que seu método analítico busca "desconsiderar a negaçâo", de modo a extrair o "puro conteúdo da ideia", haja vista que "negar algo (...) no fundo significa: isto é uma coisa que eu preferiria reprimir" (FREUD, 2014, p. 14). Contudo, faz-se necessário ressaltar que "desconsiderar" a negaçâo, nesse caso, náo implica que ela deva ser ignorada por năo ser importante; pelo contrário, a presença da negaçâo revela a inquietude do analisando.

Para a Psicanálise freudiana, a presença da negaçăo expressa a sua própria ausência, uma vez que anuncia um domínio outro, fruto da subjetividade do falante (analisando). Ou seja, a presença da negaçâo na fala do analisando revela sua preocupaçăo em reprimir o inaceitável. Deve ser, portanto, desconsiderada - mas jamais ignorada - pelo analista durante o trabalho analítico.

Já para Martin e Rose (2007, p. 280), a negaçăo implica o seu oposto, "algo no ar" que está sendo negado. Esse "algo no ar" pode revelar nâo apenas a concretude objetiva do discurso de quem se pronuncia por meio da fala ou da escrita, mas, sobretudo, o incompleto, a lacuna, que abre caminho para aspectos subjetivos inconscientes. Assim, percebemos que a LSF aponta para uma funçăo concreta do uso da negaçáo, uma vez que esta anuncia uma relaçâo de oposiçấo na concretude do texto. De acordo com Pagano (1994, p. 254), por meio da negaçăo, é possível, por exemplo, negar uma expectativa do leitor ou esclarecer ambiguidades, de forma a evitar interpretaçôes errôneas.

Enquanto para Freud as negaçōes devem ser desconsideradas, com base na perspectiva semântico-discursiva que adotamos neste estudo, nossa hipótese é que somente na identificaçăo concreta das negaçôes na superfície linguística das falas e escritas é que as negaçōes podem ser repensadas ou desconsideradas, como prefere Freud, mas nunca apagadas, porque têm papel discursivo fundamental à construçâo de sentidos subjetivos. Esse aspecto sugere que a voz narrativa, no caso Rodrigo $S$. M., projeta suas frustraçôes e desejos recalcados na personagem principal, Macabéa. Isso porque as negaçóes sâo formas de defesa do Eu contra sensaçóes ou ideias indesejadas. Nesse aspecto, perguntamos até que ponto as negaçōes presentes na voz narrativa de A Hora da Estrela revelam aspectos (ficcionais) subjetivos em relaçăo a Macabéa, personagem principal? Como esse fenômeno discursivo foi traduzido por Benjamin Moser? 
De modo a respondermos a essas perguntas, no que se segue, discorremos brevemente sobre a traduçăo e a Psicanálise. Em seguida, apresentamos o corpus da pesquisa e seus aspectos gerais. Depois, descrevemos os procedimentos metodológicos e apresentamos as análises de trechos da obra, em situaçăo comparativa - original e traduçâo -, que apresentaram escolhas explícitas de negaçóes do narrador Rodrigo S. M. acerca da personagem principal, Macabéa. Por fim, tecemos as consideraçóes finais.

\section{TRADUÇÃO E PSICANÁLISE EM A HORA DA ESTRELA}

De acordo com Frota (2015), Traduçăo e Psicanálise podem se articular de diversas formas, com motivaçôes distintas. Se, por um lado, a "traduçāo da psicanálise" discute traduçôes dadas a termos psicanalíticos, as "traduçóes na psicanálise" sâo aquelas que se dăo no âmbito da psique ou no da clínica psicanalítica. Já a chamada "psicanálise na traduçăo" é outra interface entre esses campos que, assim como as demais experiências de sujeito, se constitui de linguagem e desejo. Nessa abordagem, traduzir e teorizar a traduçâo ignorando os "ensinamentos" da psicanálise significa desconsiderar que sujeito e linguagem sâo regidos segundo a ordem do desejo do inconsciente.

Este estudo considera a Linguística do Texto e a Psicanálise como sendo complementares, dado que as produçôes discursivas revelam, em parte, os desejos mais recônditos de quem se comunica. É nessa linha de raciocínio que texto e subjetividade se encontram para desvelarem, por meio da análise textual, as marcas do inconsciente na superfície dos textos.

Na Psicanalise só há sujeito porque há linguagem: é no simbólico, em nosso assujeitamento a ele, que nos tornamos sujeito; o sujeito da Psicanalise é o sujeito do desejo do inconsciente e é de linguagem que este se faz, nela se dando (veladamente) a ver. (FROTA, 2015, p. 288)

Todo o œuvre de Clarice Lispector, em especial A Hora da Estrela, constitui-se de meandros subjetivos nos e pelos quais personagens se revelam discreta ou explicitamente por meio da voz narrativa. Sua obra foi marcada pela inquietude, pelo desconforto de um Real, segundo Lacan, impossível, porque desvela a imanência do sujeito do inconsciente, portanto, difícil de simbolizar (Cf. LACAN, 1998). Posteriormente à sua morte, um amigo escreveu:

Clarice era uma estrangeira. Năo porque nasceu na Ucrânia. Criada desde menininha no Brasil, era tăo brasileira quanto náo importava quem. Clarice era estrangeira na terra. Dava a impressâo de andar no mundo como quem desembarca de noitinha numa cidade desconhecida onde há greve geral de transportes. (GOTLIB, 1995, p.485 apud MOSER, 2009, p. 13)

Sua personalidade introspectiva e misteriosa revela-se por meio de sua prosa igualmente enigmática e singular. Em carta à Hilda Hilst, Caio Fernando de Abreu conta sobre seu primeiro contato com Clarice, e revela sentir-se intimidado e ao mesmo tempo completamente admirado por "[aquela] mulher linda e estranhíssima". Impactado com sua estranheza e empolgado com o fato de tê-la conhecido pessoalmente, o autor escreve: 
Ela é exatamente como os seus livros: transmite uma sensaçăo estranha, de uma sabedoria e uma amargura impressionantes. É lenta e quase năo fala. Tem olhos hipnóticos, quase diabólicos. E a gente sente que ela náo espera mais nada de nada nem de ninguém, que está absolutamente sozinha e numa altura tal que ninguém jamais conseguiria alcançá-la. Muita gente deve achá-la antipaticíssima, mas eu achei linda, profunda, estranha, perigosa. É impossível sentir-se à vontade perto dela, năo porque sua presença seja desagradável, mas porque a gente pressente que ela está sempre sabendo exatamente o que se passa ao seu redor. Talvez eu esteja fantasiando, sei lá. Mas a impressáo foi fortíssima, nunca ninguém tinha me perturbado tanto (ABREU, 2002).

Em 28 de dezembro de 1977, dias após seu falecimento, a TV Cultura leva ao ar a entrevista de Clarice Lispector ao jornalista Júlio Lerner do programa Panorama Especial, atendendo ao pedido da autora de que o programa apenas fosse transmitido postumamente - trata-se do único registro audiovisual da autora, que nele se mostra reservada, imprevisível e aparentemente pouco à vontade (GOTLIB; IMS, 2004). Questionada pelo jornalista sobre em que momento decide assumir sua carreira como escritora, afirma nunca ter admitido isso por năo se considerar uma escritora profissional: "eu sou amadora, e faço questâo de continuar sendo amadora". Para ela, um escritor profissional é aquele que tem uma obrigaçâo para com a escrita; e continua: "faço questăo de năo ser profissional para manter minha liberdade" (PANORAMA ESPECIAL, 1977).

Durante a entrevista, Clarice brevemente resume a obra que acabara de terminar. Sem citar o título, nem o nome da protagonista, conta que se trata da "história de uma moça tăo pobre que só comia cachorro-quente. Mas a história năo é só isso, é sobre uma inocência pisada, de uma miséria anônima" (LISPECTOR, 1977); e acrescenta: "Esta história acontece em estado de emergência e calamidade pública. Trata-se de um livro inacabado porque lhe falta a resposta" (LISPECTOR, 2017, p. 46). Sobre o cenário da novela, a escritora conta que a inspiraçăo para escrever o romance teria surgido após um passeio pela Feira de Sáo Cristóvâo, polo da cultura nordestina no Rio de Janeiro, onde Clarice afirma ter captado "o ar meio perdido do nordestino no Rio de Janeiro". Uma ida à cartomante teria, em outro momento, influenciado o desenvolvimento da trama, uma vez que logo após ter ouvido diversas previsóes positivas para seu futuro, Clarice se imaginou sendo atropelada por um táxi ao atravessar a rua (PANORAMA ESPECIAL, 1977).

Benedito Nunes (1989) aponta para a existência, em A Hora da Estrela, de uma outra presença, que disputa com a do narrador Rodrigo S. M., qual seja a da própria escritora Clarice Lispector. Nesse caso, a presença da escritora, já declarada na dedicatória da obra [“Dedicatória do autor (na verdade Clarice Lispector)]" se estenderia ao longo do romance, passando a confrontar-se com a identidade fictícia de seu personagem. Assim, Nunes compara Clarice a Flaubert, na medida em que defende o fato de Clarice ser o narrador de A Hora da Estrela e ao mesmo tempo Macabéa, tanto quanto Flaubert foi Madame Bovary. Contudo, ao contrário de Flaubert, que permanece como narrador, sempre por trás de seus personagens, Clarice "se exibe quase sem disfarce ao lado de Macabéa":

Também ela persona, em sua condiçăo patética de escritora (culposa relativamente à moça nordestina), finge ou mente - mas sabendo que finge ou mente - para alcançar 
uma verdade humana acerca de si mesma ou de outrem. A escritora se inventa ao inventar a personagem. Está diante dela como de si mesma. (NUNES, 1989, p. 169)

Ainda de acordo com Nunes (1989), em A Hora da Estrela três histórias se conjugam em um "regime de transaçăo constante". A primeira história conta a vida de uma moça nordestina que o narrador, Rodrigo S. M., notou em meio à multidāo. A segunda é a história do narrador interposto, que reflete a sua vida na da personagem, acabando por tornar-se dela inseparável, dentro da situaçăo tensa e dramática de que participam. Já a terceira história é a da própria narrativa que, constituída a partir da ligaçâo do narrador com sua personagem, envolve o dificultoso e problemático ato de escrever (NUNES, 1989, p. 162).

A produçâo artística de Clarice Lispector como escritora inicia-se em 1943 e se estende até 1977, atravessando quatro décadas de um período extremamente crítico da história brasileira. Conforme aponta Isabel Pires (2011), a obra clariceana se desenvolveu durante o conturbado segundo governo Vargas, a crise política que sucedeu o governo de Juscelino Kubitschek e a implantaçáo da ditadura militar no Brasil, a partir de 1964. A escritora também vivenciou reflexos da Segunda Guerra Mundial (1939-1945) durante o período em que viveu com sua família na Itália e na Suíça, entre 1944 e 1949. Apesar disso, a obra clariceana foi considerada pela crítica de sua época como "alienada dos problema sociais e das questóes sócio-políticas de seu tempo", principalmente devido à abordagem existencial e ao caráter introspectivo de sua narrativa, que se tornaram a "marca por excelência" da escrita da autora (SOUZA, 2008, apud PIRES, 2011), enquanto A Hora da Estrela é tida como "a obra mais explicitamente social" de Clarice, por visivelmente trazer à tona o problema da pobreza e da marginalizaçấo das classes sociais oprimidas, configurado na personagem central do romance, Macabéa (PIRES, 2011).

\section{BENJAMIN MOSER E THE HOUR OF THE STAR}

Benjamin Moser é historiador, escritor e tradutor norte-americano. Nasceu no Texas em 1976, morou na França, e voltou aos EUA para estudar História na Brown University. Hoje vive na Holanda, onde completou mestrado e doutorado. Escreve para - New York Review of Books e para a revista Harper's e tornou-se conhecido nos EUA e no Brasil com a publicaçăo de uma biografia de Clarice Lispector em 2009, Why this world (a primeira biografia da autora em língua inglesa, traduzida para o português como Clarice,), que entrou para o National Books Critics Circle Award dos EUA. Em 2016, reuniu num só volume todos os contos da escritora em Clarice Lispector, todos os contos (GUIDIN, 2017).

Fluente em seis idiomas, o autor já publicou traduçóes do neerlandês, francês, espanhol e português. Moser conta que conheceu o trabalho de Clarice nas aulas de português que frequentava, e, encantado com sua escrita, passou anos pesquisando vida e obra de Clarice, percorrendo seus passos e empenhando-se na tarefa de lançá-la no cenário internacional. Segundo ele, Clarice iria enriquecer - e mesmo salvar - a vida daqueles que a encontrariam, uma vez que "era uma das poucas grandes artistas universais que eram, como os monumentos da UNESCO, o patrimônio de toda a humanidade" (ESPOSITO, 2015, nossa traduçăo). 
Dessa forma, Moser de fato mostra-se um verdadeiro agente, um embaixador da obra de Clarice na esfera internacional, tendo alçado a autora a um nível de recepçâo nunca antes atingido ao trazer uma dimensâo performática ao projeto de disseminaçâo de Clarice por meio de sua presença constante na mídia e em ambientes editoriais e universitários (ESTEVES, 2016, p. 32).

Insatisfeito com as traduçóes das obras de Clarice publicadas em inglês por nâo representarem a verdadeira essência da escrita da autora, Benjamin Moser se propôs a retraduzir A Hora da Estrela após ter lançado, em 2009, Why this World - sâo esses os principais fatores que justificam, nos últimos anos, um maior movimento em torno da escritora no exterior, especialmente em países de língua inglesa.

De acordo com Guidin (2017), a biografia de Moser tornou-se um bestseller devido a um arrojado trabalho de divulgaçăo e distribuiçấo, porém esta năo deve ser considerada a biografia oficial de Clarice. Segundo a pesquisadora, o "livro essencial" era, e ainda é, a biografia de Nádia Gotlib intitulada Clarice, Uma vida que se conta, de 1995, posteriormente complementada pela mesma autora em 2008, com o lançamento de Clarice fotobiografia, uma narrativa visual de história de vida e obra de Clarice, com 800 imagens. Além dessas obras, surgiram também teses e pequenas biografias, que nâo tiveram ampla divulgaçâo e, por esse motivo, foram "engolidas pela biografia de Moser." Assim, o Brasil ficou com duas Clarices: a da vasta pesquisa acadêmico-científica; e a mais recente, pop e romanceada, sob vertiginosas interpretaçōes do biógrafo americano (Cf. GUIDIN, 2017).

Em entrevistas, Moser declara que os tradutores tendem a modificar o estilo de Clarice e aproveita para defender a necessidade de se tentar preservar também no inglês a estranheza da autora, năo modificar sua sintaxe, nem tentar corrigi-la, mas deixar que esses livros choquem e ecoem com a mesma cacofonia e glória de seu inimitável português (ESPOSITO, 2015):

Os tradutores tentaram aplainá-la, corrigir sua pontuaçăo excêntrica e seu fraseado estranho. É um impulso compreensível, mas que presta a ela [autora] um desserviço: se você retira a estranheza de Clarice, você retira Clarice. Algumas das traduçóes, como The Hour of the Star, a qual acabei de publicar em minha própria versăo, levaram isso ao extremo, preenchendo cada cesura dela com fraseados excessivamente explícitos que tornaram sua prosa arrastada em vez de poética. (MOSER, 2011, nossa traduçăo).

Em outro momento, Moser aponta para a ousadia artística de Clarice e a consequente dificuldade envolvida na traduçấo de suas obras:

É uma coisa muito difícil reproduzir Clarice em outra língua, porque é uma coisa que você nunca teria coragem mesmo de colocar as coisas meio loucas que ela bota. Ainda mais que dăo certo, de certa forma. Ela bota coisas que podem parecer totalmente malucas e ela consegue fazer delas uma poesia absolutamente extraordinária. [...] Mas a ousadia dela artisticamente é uma coisa absolutamente genial! E você realmente só vê isso quando você vai palavra por palavra e frase por frase. (MOSER, 2011, apud VILELA, 2018).

Nesse sentido, optamos, neste estudo, pela atuaçăo de Moser como tradutor de A Hora da Estrela, que diz respeito à possibilidade de o tradutor ter realizado uma 
traduçăo "palavra por palavra e frase por frase", a fim de reproduzir a "ousadia" de Clarice em língua inglesa, marca de sua traduçấo.

\section{PROCEDIMENTOS METODOLÓGICOS}

Para a análise dos dados, fez-se necessário selecionar, no romance, as ocorrências explícitas e implícitas (alternativas) de negaçăo do narrador quando se referia a Macabéa. Posteriormente, tornou-se possível identificar comparativamente nessas ocorrências a presença esperada do advérbio de negaçâo "năo" e de outros advérbios que expressassem a ideia de negaçấo, como "nunca"; "jamais"; "de modo algum"; "de jeito nenhum" etc.

Após essa seleçâo geral, foi feita uma nova seleçâo das ocorrências de negaçăo presentes na voz narrativa, que se referiam exclusivamente ao estilo de vida ficcional de Macabéa (seus hábitos, sonhos, conflitos internos etc.) em ambas as obras. Feito isso, o material obtido possibilitou-nos "filtrar" somente as ocorrências em que a presença da negaçăo sinalizava uma tentativa de o narrador projetar, na personagem principal, suas frustraçóes e desejos recalcados, levando em conta a orientaçăo freudiana de que a marca discursiva da negaçăo instaura textualmente o inconsciente recalcado do narrador e seu reflexo em Macabéa, de quem Rodrigo S. M. tenta desvincular-se. Em seguida, buscamos estabelecer um diálogo entre os dois tipos de discursos de negaçăo, que se diferem em relaçăo a suas abordagens: os expressos a partir de uma perspectiva textual - na concretude do discurso - e os que se fundamentam na perspectiva psicanalítica - na subjetividade da negaçăo desconsiderada.

Os procedimentos metodológicos adotados para as análises das ocorrências de negaçăo por projeçăo presentes na voz do narrador de A Hora da Estrela, em comparaçăo com a traduçâo dessa obra para a língua inglesa feita por Benjamin Moser, pautam-se em estudos sobre negativas orientados pela Linguística SistêmicoFuncional - Pagano (1994); Martin \& Rose (2007); Halliday (2014); - em paralelo com o conceito de negaçâo e projeçâo desenvolvido por Sigmund Freud (2014[1925]) e retomados por David Zimmerman (1999). De forma a complementar a pesquisa, respaldamo-nos em alguns estudos e reflexôes imprescindíveis aos estudos de traduçấo, os quais reafirmam a interrelaçâo entre linguagem e psicanálise, assim como visam tornar ciente o fato - pouco discutido - de o fenômeno tradutório receber interpretaçôes distintas, calcadas no inconsciente do tradutor. Nesse sentido, merecem especial destaque autoras como Maria Paula Frota $(2013,2015)$ e Marta Marín-Domine (2015).

\section{ANÁLISES}

Mediante as análises das ocorrências de negaçōes presentes na voz narrativa de A Hora da Estrela, em comparaçáo com sua traduçăo para a língua inglesa feita por Benjamin Moser, tornou-se possível contabilizar cento e onze excertos em que o narrador fez uso de elementos narrativos, em suas mais variadas formas, ao se referir à personagem principal. Por meio de uma investigaçáo mais detalhada, 
porém, constatamos que em especialmente oito desses excertos, Rodrigo S. M. se projeta em Macabeá usando o adjunto modal "năo". Por meio da negaçăo, destaca-se, nos trechos analisados, a maneira como Rodrigo S. M. se apropria inconscientemente da negaçăo para tentar se distanciar ao máximo da moça nordestina, personagem principal de uma história "verdadeira embora inventada" (LISPECTOR, 2017, p. 48).

Interessante percebermos a forte necessidade de o narrador em narrar a vida de uma personagem que nele desperta atençâo, mas nâo sentimentos - é o que ele tenta convencer o leitor logo no início da narrativa:

\title{
Excerto 1:
}

“Bem, é verdade que também eu năo tenho piedade do meu personagem principal, a nordestina: é um relato que desejo frio (...) Mas a pessoa de quem falarei mal tem corpo para vender, ninguém a quer, ela é virgem e inócua, náo faz falta a ninguém." (LISPECTOR, 2017, p. 48-49)

\begin{abstract}
"Anyway, it's true that I too have no pity for my main character, the northeastern girl: it's a story I want to be cold (...) But the person I'm going to talk about scarcely has a body to sell, nobody wants her, she's a virgin and harmless, nobody would miss her." (LISPECTOR, 2014, p. 5-6)
\end{abstract}

Neste excerto, ambas ocorrências do advérbio "năo" săo exemplos de negaçōes empregadas como forma de antecipar uma reaçáo que o autor espera por parte do leitor, conforme aponta Pagano (1994, p. 258). Nesse contexto, a partir de uma perspectiva textual, seria como se o autor desejasse deixar claro para seu leitor o fato de que Macabéa nâo é sequer digna de piedade, tamanha sua irrelevância.

Porém, conforme discutido anteriormente, as observaçôes de Freud acerca da presença da negaçăo no texto nos guiam a uma interpretaçáo distinta, que propóe que a negaçăo seja utilizada inconscientemente no discurso de forma a "mascarar" o verdadeiro sentimento de quem por meio dela se expressa, nesse caso Rodrigo S. M. Nesse sentido, assim como o suposto paciente mencionado por Freud faz uso do advérbio "năo" de modo a negar a possível presença de sua măe em seu sonho, da mesma forma, o narrador de A Hora da Estrela parece utilizá-lo como uma forma de se convencer de que năo sente piedade de Macabéa - porém o contrário acontece, conforme observamos ao longo da história. Ainda neste excerto, percebemos outra ocorrência da negaçăo utilizada como tentativa de ressaltar a "insignificância" da moça.

Ao afirmar que Macabéa "năo faz falta a ninguém", Rodrigo S. M. visa reforçar seu desprezo pela personagem. Na traduçáo, Moser optou pelo pronome indefinido nobody - uma alternativa de negaçâo -, que na oraçâo exerce o papel de sujeito (nobody would miss her), enquanto que no texto-fonte, "ela", no caso Macabéa, exerce o papel de sujeito da oraçâo completa: “... ela é virgem e inócua, năo faz falta a ninguém." Parece-nos que na traduçâo Rodrigo S. M. divide suas impressôes com outrem, nesse caso, nobody, ao passo que no texto-fonte ele imputa a si todas as impressóes acerca da moça. Parece-nos, ainda, que nesse trecho Moser imprimiu um certo distanciamento do narrador dividindo suas impressōes, embora se saiba 
que o que está em discussăo aqui năo é a literalidade, mas, sim, as peculiaridades que cada língua carrega e que acabam desvelando intençóes antes preferidas submersas ou, talvez, recalcadas. Assim como em muitos fragmentos da obra, a escrita se revela como uma espécie de catarse para Rodrigo S. M.

Teria, porém, outro escritor notado a delicada existência de uma garota que perambula solitária pelas ruas de uma cidade toda feita contra ela? Rodrigo S. M. náo apenas a notou, mas se propóe a escrever sobre ela:

\section{Excerto 2:}

"Por que escrevo? (...) Escrevo portanto náo por causa da nordestina mas por motivo grave de "força maior", como se diz nos requerimentos oficiais, por 'força de lei'." (LISPECTOR, 2017, p. 52)

"Why do I write? (...) So I'm not writing for the northeastern girl but for the serious reason of 'force majeure', or as they say in official documents, by 'force of law." (LISPECTOR, 2014, p. 9)

Por meio da negaçâo, o narrador parece antecipar um possível pensamento por parte do leitor, e aproveita para rejeitá-lo de antemáo. É como se o narrador dissesse a seu leitor: "se pensa que escrevo por causa da nordestina, está muito enganado". Pelo método analítico freudiano, teríamos, nessa negaçăo, um mecanismo de defesa que se concretiza no discurso a partir da repressâo de algo indesejado. Percebemos que, na verdade, o motivo de "força maior" que compele Rodrigo S. M. a escrever essa história é a própria Macabéa, pois como veremos a seguir, a escrita será sua única forma de se aliviar do "peso" da moça:

\section{Excerto 3:}

“Pois a datilógrafa náo quer sair dos meus ombros." (LISPECTOR, 2017, p. 56)

“Well the typist doesn't want to get off my shoulders." (LISPECTOR, 2014, p. 13)

Percebemos que o narrador náo aceita conferir diretamente à moça o motivo de sua escrita, mas sim à necessidade de dela se defender, pois ela exerce peso em seus ombros e em sua consciência; consequentemente, năo falar sobre ela o sufocaria. "Como escrevo?" (LISPECTOR, 2017, p. 52), pergunta-se amedrontado. Por sequer saber o nome da moça, receia iniciar a história, pois percebe que o que se propóe a narrar aparenta ser simples, mas na verdade é de difícil elaboraçăo:

\section{Excerto 4:}

"Agora năo é confortável: para falar da moça tenho que náo fazer a barba durante dias e adquirir olheiras escuras por dormir pouco, só cochilar de pura exaustâo, sou um trabalhador manual. Além de vestir-me com roupa velha rasgada. Tudo isso para me pôr no nível da nordestina." (LISPECTOR, 2017, p. 54)

"It's not comfortable now: to speak of the girl I can't shave for days and must acquire dark circles under my eyes from lack of sleep, nodding off from sheer exhaustion, I am a manual laborer. Besides wearing old ragged clothes. All in order to put myself on the northeastern girl's level." (LISPECTOR, 2014, p. 11) 
Nesse excerto, o papel semântico das negaçóes adota como que o reverso de seus usos frequentes pelo narrador: dessa vez, é Rodrigo S. M. que idealiza um desejo que textualmente pertence a Macabéa, mas que psicanaliticamente parte dele mesmo. Ou seja, parece-nos que, pela voz narrativa, Macabéa colocou condiçóes para que o narrador estivesse apto a falar dela: "nâo fazer a barba", "adquirir olheiras escuras" e "cochilar de pura exaustăo". Todavia, esses sâo desejos recalcados de Rodrigo S. M. que ele mesmo projeta em Macabéa, como se fossem uma condiçâo sine qua non para a sua existência. Se ele adotasse uma postura diferente, ele estaria "confortável", sensaçăo que, paradoxalmente, causar-lhe-ia desconforto. O tradutor capturou as mesmas impressóes em suas escolhas linguísticas, acionadas pela presença das negaçôes nos textos.

A mudança de hábito relatada por Rodrigo S. M. garantirá ao narrador a sensaçáo de aproximar-se do que é ser a nordestina. Textualmente, ele tenta nos convencer de que está tăo distante da realidade da moça que para escrever sobre ela precisará se apresentar à sociedade da forma como ela se apresenta. Porém, inconscientemente, assume ter conhecimento de que o assunto do qual tratará já está de algum modo naturalmente escrito nele próprio:

\section{Excerto 5:}

"Vai ser difícil escrever esta história. Apesar de eu náo ter nada a ver com a moça, terei de me escrever todo através dela por entre espantos meus." (LISPECTOR, 2017, p. 58)

"It's going to be hard to write this story. Even though I don't have anything to do with this girl, I'll write out all of myself through her amidst frights of my own." (LISPECTOR, 2014, p. 16)

Neste excerto, a negaçăo expressa a rejeiçăo da possibilidade de haver qualquer traço que o aproxime da moça. Porém, logo em seguida o narrador se contradiz, uma vez que, de forma inconsciente, nos revela que dirá muito de si mesmo por meio de sua personagem. Na traduçáo, embora Moser tenha seguido o estilo de Clarice, recursos mais elaborados da língua inglesa, como "amidst frights of my own", típicos do discurso literário, serviram aos propósitos do tradutor de respeitar as escolhas linguísticas muito próprias de Clarice Lispector.

Ao afirmar que a"moça nâo se conhece senăo através de ir vivendo a toa"(LISPECTOR, 2017, p. 50), o narrador a compara a uma "cadela vadia, teleguiada exclusivamente por si mesma"(LISPECTOR, 2017, p. 53); alguém que năo se sentia infeliz por náo saber que era o que era, da mesma forma que "um cachorro náo sabe que é cachorro" (LISPECTOR, 2017, p. 60). Teria ela algum propósito na vida? Para ele, ela era um acaso.

\section{Excerto 6:}

"Mas eu, que náo chego a ser ela, sinto que vivo para nada". (LISPECTOR, 2017, p. 64-65)

"But I, who can't quite be her, feel that I live for nothing". (LISPECTOR, 2014, p. 24)

Uma explicaçăo para essa frase emblemática de Rodrigo S. M. em relaçăo a Macabéa é que, ao longo da obra, percebemos que o narrador utiliza seu ofício de escritor como justificativa para se livrar da aceitaçâo de também ser um acaso: "Quanto a mim, só me 
livro de ser apenas um acaso porque escrevo, o que é um ato é um fato" (LISPECTOR, 2017, p. 68). Apesar disso, ele sente que escreve por năo ter mais nada a fazer enquanto espera a morte, escreve como uma forma de escapar de seu papel de ser - ser miserável é perder-se no vazio de si mesmo. Quanto à nordestina, apesar de sua "pobreza feia e promíscua", "náo havia nela miséria humana" (LISPECTOR, 2017, p. 70), por isso nâo se sentia infeliz. Ela se contentava em ser datilógrafa, virgem e em gostar de Coca-Cola. Diferente de seu narrador, a personagem "tinha em si mesma uma certa flor fresca" (LISPECTOR, 2017, p. 70) que a fazia acreditar e existir. Moser, na traduçăo, seguiu o mesmo estilo de Lispector, enfatizando as sensaçóes melancólicas de Rodrigo S. M. quando defrontado por Macabéa.

\section{Excerto 7:}

"A moça é uma verdade da qual eu năo queria saber. Nấo sei a quem acusar mas deve haver um réu." (LISPECTOR, 2017, p. 70)

"The girl is a truth I didn't want to know about. I don't know whom to accuse but somebody has to have done it." (LISPECTOR, 2014:31)

Observamos a forma como Rodrigo S. M. se compadece da situaçăo de sua personagem através da negaçăo. Em um primeiro momento, ele próprio se sente culpado por ocupar uma posiçăo social confortável para os parâmetros da época: possui um lar, vinho, uma máquina de escrever [...] Enquanto Macabéa, "nem se dava conta de que vivia numa sociedade técnica onde ela era um parafuso dispensável" (LISPECTOR, 2017, p. 62). Posteriormente, o narrador se alivia da culpa, imputando-a a outra pessoa, a quem ele denomina "réu".

Assim como nessa passagem do texto, se retornamos ao segundo excerto anteriormente analisado, observamos a escolha de Clarice por termos jurídicos para enfatizar a preocupaçâo do narrador em relaçâo a Macabéa. No segundo excerto, "motivo de 'força maior"' e "força de lei" expressam o impacto que a moça exerce na consciência de seu narrador, algo que por ele já năo mais pode ser evitado ou disfarçado. Em sua traduçăo, Moser mantem tais termos jurídicos, porém o mesmo năo ocorre no sétimo excerto com a palavra "réu". Assim, observa-se que o tradutor retira o peso jurídico da fala do narrador situando-a no campo discursivo do equívoco. Ou seja, enquanto o texto original constata a presença de um culpado aos olhos da lei, a traduçáo aponta para o fato de que alguém fez algo errado, mas năo necessariamente ilegal.

Ao longo da história, percebemos uma gradaçâo nas intençôes de Rodrigo S. M. conforme narra a gravidade da situaçâo da moça que, após um trágico atropelamento, ficou caída no canto da rua, "descansando as emoçôes" (LISPECTOR, 2017, p. 105). Primeiramente nos diz que năo falou e nem falará em morte e sim apenas em um atropelamento, porém, em seguida, muda seu discurso:

\section{Excerto 8:}

"Vou fazer o possível para que ela náo morra. Mas que vontade de adormecê-la e de eu mesmo ir para a cama dormir." (LISPECTOR, 2017, p. 105)

"I'm going to do everything I can to keep her from dying. But what an urge to put her to sleep and to go off to bed myself". (LISPECTOR, 2014, p. 71) 
Inicialmente o narrador revela a intençăo de preservar a vida de Macabéa, uma vez que assume se esforçar para que ela năo morra. No entanto, considerando a sentença que segue, bem como o fato de que a negaçâo também pode encobrir algo inconscientemente reprimido do narrador, percebemos que, por trás da negaçâo presente em sua fala, se esconde uma crescente intençáo de busca pelo fim da imagem de sofrimento e luta da jovem nordestina - o que finalmente o leva a desejar a morte da moça como alívio ou soluçăo para seu próprio conflito interior.

Na traduçăo desse excerto, observa-se uma certa intensificaçăo da ideia expressa no texto original, na medida em que o tradutor faz uso do pronome "everything" para expressar que o narrador fará "tudo que puder" para evitar a morte da personagem; enquanto o excerto original năo exprime o mesmo sentimento de esforço por parte do narrador. Além disso, a negaçăo do texto original é substituída, na traduçăo, pelo phrasal verb "keep (her) from", seguido do verbo no gerúndio, sem, contudo, alterar o sentido da frase, pois a ideia de se evitar a morte da personagem é mantida na traduçăo.

Essa passagem, que se aproxima do fim da obra, prepara o leitor para a hora em que a estrela de Macabéa finalmente vai brilhar. Sua morte desencadeia a morte declarada seu narrador Rodrigo S. M.: "Macabéa me matou. Ela estava enfim livre de si e de nós." (LISPECTOR, 2017, p. 109), e a de Clarice que, em entrevista após ter finalizado o livro, assume se sentir morta: "Bom, agora eu morri. Mas vamos ver se eu renasço de novo. Por enquanto eu estou morta. Estou falando do meu túmulo" (PANORAMA, 1977).

\section{CONSIDERAÇÕES FINAIS}

Considerando os estudos sobre negativas, tanto os expressos a partir de uma perspectiva textual como os que se fundamentam por meio da psicanálise, nota-se que tanto a LSF quanto a Psicanálise consideram que a negaçáo está marcada na textura do texto. Porém, as divergências em relaçâo a essas duas abordagens se dăo porque, de um lado, a LSF vê a negaçăo como núcleo de polaridade e, de outro, a Psicanálise a vê como falta, ausência, embora presente no texto.

Em outras palavras, para a LSF, a negaçăo expressa uma materialidade concreta, pois anuncia em si a ideia contrária, a oposiçăo, a negativa per se, no texto. Já para a Psicanálise, a negaçâo expressa uma materialidade subjetiva, pois sua presença marca a sua própria falta, por anunciar um domínio outro, fruto da subjetividade do falante (analisando). A importância da negaçăo, nesse caso, consiste no fato de que sua falsa existência serve para ocultar sua verdadeira ausência.

Nesse sentindo, por meio das análises das ocorrências de negaçăo na voz narrativa de A Hora da Estrela, em comparaçăo com a traduçăo The Hour of the Star, concluímos que as negaçóes de Rodrigo S. M. anunciam seu incômodo próprio, projetado em Macabéa, personagem que incialmente é por ele menoscabada, desprezada, até odiada, mas que, ao longo da trama, imprime no narrador sua força, oriunda de sua singeleza e ingenuidade. Nesse processo, Rodrigo S. M., ao negar-se em Macabéa, acaba por descobrir-se e reconhecer-se nela, o que só foi possível de ser percebido graças à presença da negaçăo em seu texto. Ou seja: 
Lidar com o nosso inconsciente é também lidar com o desconforto, com o que queremos que seja inominável e que permaneça esquecido; mas, o inconsciente, que tem suas 'artimanhas', prega-nos peças constantemente. Podemos dizer que também somos o que insistimos em esquecer. (RODRIGUES-JÚNIOR, s/d)

A partir das análises dos excertos de negaçáo traduzidos por Benjamin Moser, observa-se o esforço do tradutor no sentido de respeitar e reproduzir, em língua inglesa, a singularidade - e profundidade - da escrita de Clarice, ao mesmo tempo em que busca preservar ao máximo, em termos de linguagem e sintaxe, o estilo da autora. Apesar de geralmente ter se aproximado de forma considerável do texto de partida, observa-se também momentos, como no caso do quinto excerto analisado, em que o tradutor extrapola a traduçâo "palavra por palavra e frase por frase" - expressâo usada por ele mesmo -, mostrando que é possível utilizar recursos bastante elaborados da língua inglesa, sem, contudo, alterar a ideia expressa pelo texto original.

Por fim, a presente pesquisa visa trazer contribuiçōes para o campo da traduçăo literária, uma vez que se debruça sobre um aspecto pouco explorado nos Estudos da Traduçăo, o qual trata da interrelaçâo entre linguagem, pelo viés da Linguística Sistêmico Funcional, e Psicanálise, especificamente a (de)negaçăo como mecanismo de defesa do Eu. Neste estudo, também percebemos nosso inescapável assujeitamento ao desejo do inconsciente, essa dimensấo de poderosos pensamentos que acontecem à nossa revelia (FROTA, 2013). Nesse sentido, conforme explora Marín-Dòmine (2015), a prática psicanalítica é, em si mesma, uma prática de traduçăo: traduçăo do desejo do inconsciente, expresso de forma velada, para a linguagem comum da consciência. 


\section{REFERÊNCIAS}

ESPOSITO, S. Passionate Acolytes: An Interview with Benjamin Moser. The Paris Review, 17 agosto 2015. Disponível em: < https://bit.ly/2YmF6SN> Acesso em: 16 dez. 2019.

ESTEVES, Lenita Maria Rimoli. A presença da literatura brasileira no exterior e a importância do agenciamento: uma análise guiada por conceitos da sociologia de Pierre Bourdieu. 0 eixo e a roda, Belo Horizonte, v. 25, n. 1, p. 9-36, 2016.

FREUD, Sigmund. A negaçăo. Traduçâo Marilene Carone e James Strachey. Săo Paulo: Cosac Naify, 2014 [1925].

FROTA, M. P. Prefácio. In: MARÍN-DÒMINE, M. Traduzir o Desejo: psicanálise e linguagem. Traduçăo Emiliano de Brito Rossi. Belo Horizonte: Editora da UFMG, 2015. p. 15-21.

FROTA, M. P. Traduçâo \& psicanálise - um encontro a convite de Freud. In: AMORIM, LM., RODRIGUES, CC., e STUPIELLO, ÉNA., orgs. Traduçâo \&: perspectivas teóricas e práticas [online]. Sâo Paulo: Editora UNESP; Săo Paulo: Cultura Acadêmica, 2015, pp. 277-302. ISBN 978- 85-68334-61-4.

FROTA, M. P. A escrita do inconsciente no texto traduzido. Escrita (PUCRJ), v. 17, p. 1-15, 2013.

GUIDIN, M.L. Uma biografia pop: Benjamin Moser e Clarice Lispector. BRASIL/BRAZIL: Revista de Literatura Brasileira. [online]. 2017, vol. 30, n.56, p. 97-108. Disponível em: 〈https://seer.ufrgs.br/brasilbrazil/article/view/80296/47136〉. Acesso em: 03 mar. 2020.

HALLIDAY, M. A. K.; MATHIESSEN, C. M. I. M. An Introduction to Functional Grammar. 3ed. Londres; Nova York: Arnold, 2004.

IMS. INSTITUO MOREIRA SALLES. Cadernos de literatura brasileira: Clarice Lispector. Ediçâo especial, n. 17 e 18. Sáo Paulo: Instituto Moreira Salles, 2004.

LACAN, J. Para além do "Princípio da realidade". In: Escritos. Trad. Vera Ribeiro.

Rio de Janeiro: Zahar, 1998. p. 77-95.

LISPECTOR, C. A Hora da Estrela. 1ed. Rio de Janeiro: Rocco, 2017.

LISPECTOR, C., The Hour of The Star. Traduçăo Benjamin Moser. London, England: Penguin G, 2014.

MARÍN-DÒMINE, M. Traduzir o Desejo: psicanálise e linguagem. Trad. Emiliano de Brito Rossi. Belo Horizonte: Editora da UFMG, 2015.

MARTIN; J. R.; ROSE, D. Working with Discourse: meaning beyond the clause. 2ed. Londres e Nova York: Continuum, 2007.

MONCONT, Italo (org.). Cartas: Caio Fernando Abreu. Rio de Janeiro: Aeroplano, 2002.

MOSER, B.Brazil's ClariceLispector GetsaSecondChanceinEnglish.Publishing Perspectives, 2 dezembro 2011. Disponível em: <https://bit.ly/2Yn8c4A> Acesso em: 17 dez. 2019.

MOSER, B. Clarice, uma biografia. Traduçăo Jóse Geraldo Couto. Săo Paulo: Cosac Naify, 2009. 
NUNES, B. 0 drama da linguagem: Uma leitura de Clarice Lispector. Sáo Paulo: Ática, 1989.

PAGANO, A. S. Negatives in written text. In: COULTHARD, M., Advances in Written Text Analysis. 1ed. London and New York: Routledge, 1994.

"Panorama Especial com Clarice Lispector". TV Cultura. Săo Paulo. Entrevista a Júlio Lerner. Gravada em 01.02.77 e exibida no dia 28.12.77, às 20h30. Disponível em: <https:// www.youtube.com/watch?v=ohHP112EVnU> Acesso em: 02 jan. 2020.

PIRES, I. V. Clarice Lispector e a contracena da História em A hora da estrela. Semina: Ciências Sociais e Humanas. [online] v. 32, n. 1, p. 9-24, 2011. Disponível em: <http://www. uel.br/revistas/uel/index.php/seminasoc/article/view/10404> Acesso em: 20 maio 2020. RODRIGUES-JÚNIOR, A. S. A Negaçăo como Mecanismo de Repressăo. Manuscrito. s/d. VILELA, L. A Hora da Estrela, de Clarice Lispector: aspectos estilísticos e linguísticos em duas traduçóes para o inglês. 2018. 181f. Dissertaçăo (Programa de Pós-Graduaçăo em Estudos Da Tradução), UnB, Brasília, 2018.

ZIMERMAN, David E. Fundamentos psicanalíticos: teoria, técnica e clínica. Porto Alegre, RS:Artmed, 1999. 